5. De Lorenzi F, Hubner G, Rotmensz N, et al. Oncological results of oncoplastic breast-conserving surgery: long term follow-up of a large series at a single institution: A matched-cohort analysis. Eur J Surg Oncol 2016;42:71-7.

\section{Response to Letter: Evolving Trends in Breast Surgery: Oncoplastic to Onco- Aesthetic Surgery}

\author{
Amtul Razzaq Carmichael, Kefah Mokbel \\ The London Breast Institute, The Princess Grace Hospital, London, UK \\ Correspondence: Amtul R Carmichael \\ The London Breast Institute, The Princess Grace Hospital, 42-52 Nottingham Place London W1U 5NY \\ UK \\ Tel: +44-20-7908-2040, Fax: +44-207-908-22, E-mail: amtulcarmichael@googlemail.com \\ No potential conflict of interest relevant to this article was reported.
}

Received: 9 Sep $2016 \bullet$ Revised: 14 Oct $2016 \bullet$ Accepted: 18 Oct 2016 pISSN: 2234-6163• eISSN: 2234-6171

https://doi.org/10.5999/aps.2017.44.1.86• Arch Plast Surg 2017:44:86

Copyright (C) 2017 The Korean Society of Plastic and Reconstructive Surgeons

This is an Open Access article distributed under the terms of the Creative Commons Attribution

Non-Commercial License (http://creativecommons.org/licenses/by-nc/4.0/) which permits

unrestricted non-commercial use, distribution, and reproduction in any medium, provided the original work is properly cited.

We thank the editors for giving us an opportunity to respond to this letter. We also thank the authors of the letter for their interest in our article and their kind comments. The authors seem to imply that oncoplastic breast surgery (OBS) is restricted to breast-conserving surgery for large tumours. However, OBS also refers to the techniques of skin-sparing mastectomy and immediate reconstruction and breast-conserving surgery for small tumours.

We agree that overall and disease-free survival are the main aims of cancer treatment, and that these aims can be attained effectively by standard breast-conserving surgery procedures. We welcome the words of caution given in the letter that oncological safety must take precedence over cosmetic outcome. OBS does not require wider tumour-free margins than standard breast conservation treatment, and we consider a tumour-free margin of $2 \mathrm{~mm}$ to be adequate. The tumour's cavity can be marked with metallic clips in order to guide the delivery of radiotherapy, if required.
We would most respectfully disagree with the assertion that oncoplastic breast conserving surgery has a negative impact on patient outcome in terms of survival and morbidity. There is robust evidence that oncoplastic breast conserving surgery provides excellent disease-free survival (96\% at 7 years) [1]. Oncoplastic breast conserving surgery presents a viable alternative to standard wide local excision which is shown to be associated with a high re-excision rate (12.9\% vs. 6.5\%) [2]. The incidence of local control and survival has been shown to be similar for locally advanced breast cancer between oncoplastic and non-oncoplastic breast conserving surgery. These results have been replicated in large series with long follow-up with high $(88 \%)$ patient satisfaction with the aesthetic outcome $[3,4]$.

The authors of the letter state that oncoplastic breast procedures are associated with a higher rate of complications. The analyses from the American College of Surgeons National Surgical Quality Improvement Program database confirm that the use of OBS does not confer an increased risk of surgical complications, despite the longer operative time [5]. Thus, the role of adequate training, informed patient consent and appropriate patient selection cannot be over-emphasised. We assert that we do not advocate attainment of aesthetic excellence at the expense of compromise of oncological safety. Our article purports to say that it is possible to attain both these objectives in a vast majority of patients with surgical techniques, planning, and training.

\section{References}

1. Nizet JL, Maweja S, Lakosi F, et al. Oncological and surgical outcome after oncoplastic breast surgery. Acta Chir Belg 2015;115:33-41.

2. Cali Cassi L, Vanni G, Petrella G, et al. Comparative study of oncoplastic versus non-oncoplastic breast conserving surgery in a group of 211 breast cancer patients. Eur Rev Med Pharmacol Sci 2016;20:2950-4.

3. De Lorenzi F, Hubner G, Rotmensz N, et al. Oncological results of oncoplastic breast-conserving surgery: long term follow-up of a large series at a single institution: a matched-cohort analysis. Eur J Surg Oncol 2016;42:71-7.

4. Rezai M, Knispel S, Kellersmann S, et al. Systematization of oncoplastic surgery: selection of surgical techniques and patient-reported outcome in a cohort of 1,035 patients. Ann Surg Oncol 2015;22:3730-7.

5. Cil TD, Cordeiro E. Complications of oncoplastic breast surgery involving soft tissue transfer versus breast-conserving surgery: an analysis of the NSQIP database. Ann Surg Oncol 2016;23:3266-71. 